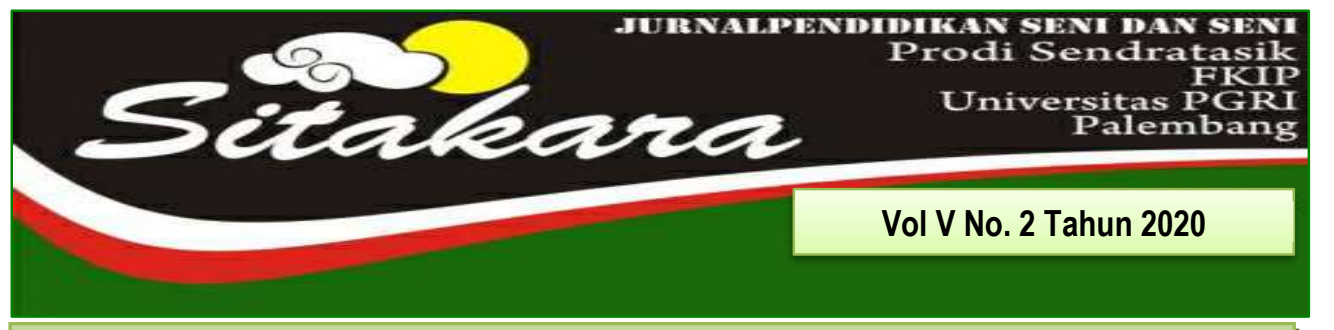

FUNGSI DAN MAKNA BHAJAN PADA UPACARA AGAMA HINDU DI KUIL SHRI MARIAMMAN KOTA MEDAN

(Agung Suharyanto, dkk)

KESENIAN SRANDUL DALAM UPACARA BERSIH DESA BULU KALURAHAN KARANGMOJO KECAMATAN KARANGMOJO KABUPATEN GUNUNGKIDUL YOGYAKARTA

(Supriyanto)

FUNGSI DAN MAKNA LAGU GUBANG DALAM UPACARA SIAR MAMBANG PADA MASYARAKAT TANJUNGBALAI

(Theo henry tua siagian ${ }^{1}$, pulumun p. Ginting ${ }^{2} \&$ wiflihani)

FUNGSI TARI MAPAK ADAT MUARA KUANG SEBAGAI TARI SAMBUT

(Nadia Rahma Aprilia', Dessy Wardiah², Treny Hera ${ }^{3}$ )

MAKNA SIMBOLIK RAGAM HIAS PADA RUMAH LIMAS PALEMBANG

(Ferri Hidayad ${ }^{1}$ Decky Kunian ${ }^{2}$ )

GAYA MUSIK SAHILIN DALAM KESENIAN MUSIK BATANGHARI SEMBILAN DI KOTA PALEMBANG

(Feri Firmansyah)

TRANSPOSISI TTI (TRANSFER, TRANSLATION, IMITATE) DALAM PEMBELAJARAN NOTASI MUSIK MELALUI SCORE CREATOR

(A Heryanto ${ }^{1}$ Dedy Firmansyah ${ }^{2}$ )

RASE TAK SERUPE MUSIK MELAYU TRADISI DENGAN PENGEMBANGAN MUSIK MODERN DALAM RUANG PERTUNJUKAN KOMPOSISI MUSIK NUSANTARA (Rio Eka Putra)

BENTUK SYAIR LAGU DALAM PERTUNJUKAN SYAROFAL ANAM DI PEDESTRIAN S UDIRMAN KOTA PALEMBANG

(Nofroza Yelli ${ }^{1}$ Deria Sepdwiko² ${ }^{2}$

"Betenun" Sebuah Wujud Proses Kreatif Mahasiswa Seni Pertunjukan Universitas PGRI PALEMBANG

(Nurdin $^{1}$ Naomi Diah Budi Setyaningrum ${ }^{2}$ ) 
DAFTAR ISI

FUNGSI DAN MAKNA BHAJAN PADA UPACARA AGAMA HINDU DI KUIL 1-15 SHRI MARIAMMAN KOTA MEDAN

(Agung Suharyanto, dkk)

KESENIAN SRANDUL DALAM UPACARA BERSIH DESA BULU KALURAHAN

$16-26$

KARANGMOJO KECAMATAN KARANGMOJO KABUPATEN GUNUNGKIDUL YOGYAKARTA

(Supriyanto)

FUNGSI DAN MAKNA LAGU GUBANG DALAM UPACARA SIAR MAMBANG 27-39 PADA MASYARAKAT TANJUNGBALAI

(Theo henry tua siagian ${ }^{1}$, pulumun $p$. Ginting ${ }^{2} \&$ wiflihani)

FUNGSI TARI MAPAK ADAT MUARA KUANG SEBAGAI TARI SAMBUT

40-52

(Nadia Rahma Aprilia', Dessy Wardiah², Treny Hera')

MAKNA SIMBOLIK RAGAM HIAS PADA RUMAH LIMAS PALEMBANG

53-61

(Ferri Hidayad ${ }^{1}$ Decky Kunian ${ }^{2}$ )

GAYA MUSIK SAHILIN DALAM KESENIAN MUSIK BATANGHARI SEMBILAN DI $\quad 62-76$ KOTA PALEMBANG

(Feri Firmansyah)

TRANSPOSISI TTI (TRANSFER, TRANSLATION, IMITATE) DALAM 77-85 PEMBELAJARAN NOTASI MUSIK MELALUI SCORE CREATOR (A Heryanto ${ }^{1}$ Dedy Firmansyah ${ }^{2}$ )

RASE TAK SERUPE MUSIK MELAYU TRADISI DENGAN PENGEMBANGAN MUSIK MODERN DALAM RUANG PERTUNJUKAN KOMPOSISI MUSIK NUSANTARA

(Rio Eka Putra)

BENTUK SYAIR LAGU DALAM PERTUNJUKAN SYAROFAL ANAM DI PEDESTRIAN SUDIRMAN KOTA PALEMBANG

(Nofroza Yelli ${ }^{1}$ Deria Sepdwiko ${ }^{2}$ )

"BETENUN" SEBUAH WUJUD PROSES KREATIF MAHASISWA SENI

$109-120$ PERTUNJUKAN UNIVERSITAS PGRI PALEMBANG

(Nurdin ${ }^{1}$ Naomi Diah Budi Setyaningrum ${ }^{2}$ )

86-95 


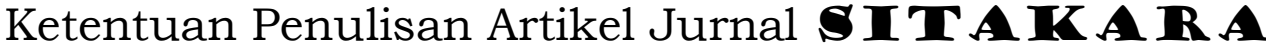

1. Naskah berbahasa Indonesia bertemakan Seni Budaya yang meliputi hasil penelitian pengajaran seni budaya, cabang seni, dan kebudayaan.

2. Naskah harus asli dan belum pernah dimuat dalam media lain. Naskah dapat berupa hasil penelitian perorangan atau kelompok.

3. Naskah ditulis dengan cara-cara yang sesuai dengan ketentuan penulisan artikel ilmiah menggunakan bahasa Indonesia yang baku, berupa ketikan, beserta soft line dalam CD-RW atau dengan mengirimkan email pada redaksi Jurnal SITAKA RA dengan alamat email: jurnalsitakarasendratasik@yahoo.com, spasi 1,5 jenis huruf Arrial Narrow ukuran 12, dengan panjang naskah antara 8-15 halaman pada kertas A4.

4. Artikel hasil penelitian memuat:

JUDUL

Nama Penulis

Abstrak

A. PENDAhuluan

B. METODE PENELITIAN

C. HASIL DAN PEMBAHASAN

D. SIMPULAN

5. Artikel kajian konseptual memuat:

JUDUL

Nama Penulis

Abstrak

PENDAHULUAN
: XXX (HURUF KAPITAL)

: (disertai jabatan dan institusi)

: (Bahasa Indonesia yang memuat 100150 kata diikuti kata kunci, dengan jenis huruf Arrial Narrow dan ukuran huruf 11 spasi tunggal serta dicetak miring)

: (Memuat latar belakang masalah, tinjauan pustaka secara ringkas, masalah penelitian dan tujuan penelitian)

: (Berisi simpulan)

\section{: XXX (HURUF KAPITAL)}

: (disertai jabatan dan institusi)

: (Bahasa Indonesia yang memuat 100150 kata diikuti kata kunci, dengan jenis huruf Arrial Narrow dan ukuran huruf 11 serta dicetak miring)

: (Memuat latar belakang masalah, tinjauan pustaka secara ringkas, 
Sub Judul

Sub Judul

SIMPULAN

DAFTAR PUSTAKA masalah penelitian dan tujuan

penelitian)

: Sesuai dengan kebutuhan (tanpa

numbering)

: (Berisi simpulan dan saran)

: (Berisi pustaka yang dirujuk dalam uraian naskah

6. Referensi sumber dalam teks artikel ditulis dengan menggunakan side note, contoh: (Jalalluddin, 1991:79); (Taufik, 2005;350); (Hamid dan Madjid, 2011:43). Sementara penulisan daftar pustaka disusun dengan ketentuan. Nama Pengarang. Tahun Terbit. Judul (dicetak miring). Kota Terbit: Nama Penerbit. Contoh: Koentjaraningrat. 2010. Manusia dan Kebudayaan Di Indonesia. Jakarta: Djambatan.

Daftar pustaka hanya memuat pustaka/sumber yang dirujuk dalam uraian dan disusun menurut abjad, tanpa nomor urut.

7. Naskah yang dimuat akan disunting kembali oleh redaksi tanpa mengubah isinya.

8. Naskah yang ditolak (tidak bisa dimuat) akan dikirim kembali ke penulis dengan pemberitahuan tertulis dari redaksi atau alamat email.

9. Penulis yang naskahnya dimuat akan mendapatkan 1 (satu) majalah nomor yang bersangkutan.

10. Contact Person: Treny Hera (085357344704) dan Mainur (081373165553). 


\title{
FUNGSI TARI MAPAK ADAT MUARA KUANG SEBAGAI TARI SAMBUT
}

\author{
Oleh:
}

\author{
Nadia Rahma Aprilia' ${ }^{1}$, Dessy Wardiah², Treny Hera ${ }^{3}$. \\ (FKIP Universitas PGRI Palembang) \\ Email: Rahmanadia23@gmail.com
}

\begin{abstract}
ABSTRAK
Penelitian ini bertujuan untuk mendeskripsikan Fungsi Tari Mapak Adat Muara Kuang Pada Kecamatan Muara Kuang Kabupaten Ogan Ilir. Penelitian ini menggunakan pendekatan kualitatif. Pengambilan dan Pengumpulan data dilakukan menggunakan teknik observasi, wawancara, dan dokumentasi. Teknik analisis data dilakukan secara deskriptif kualitatif dengan tiga tahapan yaitu reduksi data, penyajian data dan kesimpulan. Hasil Penelitian ini ditemukan tiga fungsi tari Mapak Adat Muara Kuang pada Kecamatan Muara Kuang Kabupaten Ogan Ilir, yaitu : (1) Fungsi tari Mapak Adat Muara Kuang sebagai upacara selamatan rumah, didalam rangkaian upacara tersebut terdapat pertunjukan tari Mapak Adat Muara Kuang sebagai pelengkap yang ditampilkan pada saat pembukaan upacara. (2) Fungsi kedua sebagai tontonan yaitu tari Mapak Adat Muara Kuang di adakan pada acara penyambutan tamu agung atau tamu kehormatan yang datang ke Kelurahan Muara Kuang Kecamatan Muara Kuang Kabupaten Ogan llir yang mana biasanya ucapan selamat datang disimbolkan dengan pemberian Tepak sirih oleh penari kepada tamu yang datang. (3) Fungsi ketiga sebagai hiburan yaitu tari Mapak Adat Muara Kuang yang biasa ditampilkan pada acara perkawinan, khitanan dan pesta rakyat.
\end{abstract}

Kata Kunci : Fungsi Tari , Tari Mapak Adat Muara Kuang

\section{A. PENDAHULUAN}

Sumatera Selatan merupakan salah satu provinsi yang ada di Indonesia, yang memiliki kesenian tradisional yang beranekaragam baik itu budaya dan adat istiadatnya yang berkembang di masyarakat. Kebudayaan merupakan bagian dari kehidupan manusia yang berupa hasil budi daya manusia. Kebudayaan dari berbagai suku bangsa yang sangat beraneka ragam dari masing-masing daerahnya dapat menghasilkan sebuah kebudayaan yang baru. Sejalan dengan pembahasan di atas (Koentjaraningrat, $2015:$ 146) menyatakan bahwa kata "kebudayaan" berasal dari bahasa senskerta buddhayang, yaitu bentuk jamak dari "buddhi" yang berarti "budi" atau "akal". Yakni budaya sebagai "daya budi" yang berupa cipta, karsa, sedangkan kebudayaan adalah hasil dari cipta karsa, dan rasa dari sekelompok orang.

Kesenian lahir dari kreativitas masyarakat diantaranya keadaan sosial ekonomi masyarakat dan pola kegiatan 
masyarakat sehari-hari. Kesenian berakar dari kebiasaan dan adat istiadat yang diwariskan secara turun temurun sehingga perkembangannya tidak terlepas dari kehidupan. Menurut (Bahari, 2014 : 45) kesenian merupakan unsur pengikat yang mempersatukan pedoman-pedoman bertindak yang berbeda menjadi suatu desain yang utuh, menyeluruh, dan oprasional, serta dapat diterima sebagai sesuatu yang bernilai.

Kesenian sebagai unsur kebudayaan terdiri dari berbagai cabang seni, salah satunya seni tari. Menurut (Bahari, 2014 : 57) seni tari merupakan seni yang dapat dicerap melalui indera penglihatan, dimana keindahannya dapat dinikmati dari gerakan-gerakan tubuh, terutama gerakan kaki dan tangan, dengan ritme-ritme teratur, yang diiringi irama musik yang dicerap melalui indera pendengaran. Pendapat di atas dapat disimpulkan bahwa seni tari adalah ungkapan perasaan manusia yang dituangkan melalui gerakan-gerakan yang ritmis dan indah yang selaras dengan iringan irama musik, sehingga keindahannya dapat dinikmati oleh penonton.

Tari tradisional adalah tarian khas suatu daerah yang ditarikan secara turun-temurun yang telah ada sejak dulu dan masih tetap dilestarikan hingga sekarang sehingga tari tradisional dikatakan warisan budaya untuk generasi selanjutnya. Indonesia sangat kaya akan kebudayaan terutama taritarian yang dimiliki setiap daerah yang menjadi ciri khas dari daerah tersebut, seperti Kelurahan Muara Kuang Kecamatan Muara Kuang Kabupaten Ogan Ilir Provinsi Sumatera Selatan.

Sumber penciptaan merupakan gagasan yang melandasi terciptanya sebuah karya tari (Hera, 2018: 60). Penciptaan seni menghasilkan sesuatu, menghasilkan produk yang baru, menghasilkan bentuk seni yang kreatif. Hasil daripada penciptaan yang dilahirkan seseorang mampu mengapresiasi orang banyak, dalam hal ini adalah manusia sebagai pemakai produk seni tersebut. Hendaknya penciptaan bernilai estetis, harmonis, dan mampu melahirkan pengalaman estetis. Hasil penciptaan adalah bentuk dan wujud yang dapat dipercaya. Maka dari itu penciptaan yang dilandasi oleh ilmu pengetahuan khususnya dalam bidang pendidikan akan mudah dipertanggungjawabkan secara teoritis dan dituliskan secara ilmiah, hal ini 
mampu membuat karya seni yang diciptakan memiliki nilai yang berharga, dan yang paling penting adalah suatu penciptaan tidak dan bukan mengadaada walaupun penciptaan lahir dari imajinasi manusia yang kuat sebagai manusia yang penuh daya khayal (Hera T. , $2018: 389$ )

Seni tari disetiap daerah tentu berbeda-beda, salah satunya Kabupaten Ogan llir yang merupakan bagian dari propinsi Sumatera Selatan yang memiliki beberapa kesenian tradisional yang masih membutuhkan perhatian dan perkembangan di era globalisasi ini. Pada seni tari diantaranya terdapat Tari Sambut, Tari Mapakraje, Tari Robat, Tari Tongkar, Tari Kreasi Nugal, Tari Kreasi Keris dan Tari Mapak Adat Muara Kuang.

Ada yang menarik dari salah satu tari di kabupaten Ogan llir yaitu dari tari Mapak Adat Muara Kuang. Yang menarik adalah bentuk tarinya berbeda dari taritari yang ada di Ogan llir dari segi bentuk gerak murni mewakili cerita rakyat Muara Kuang dalam meratapi nasib badan. Kelurahan Muara Kuang adalah salah satu Kelurahan yang ada di Kabupaten Ogan Ilir. Kelurahan Muara Kuang ini memiliki kesenian daerah yaitu Tembang
Batang Hari Sembilan, tembang ini bernama Tembang Nasib Muara Kuang dan tembang ini diiringi oleh sebuah tari sambut yaitu tari Mapak Adat Muara Kuang yang artinya adalah menjemput atau menyambut tamu yang datang ke daerah Muara Kuang. Tari Mapak Adat Muara Kuang mempunyai nama lain, seperti Mapak Pesira (Camat), Mapak Demang (Kepala Desa/Lurah), dan juga Mapak Penganten (Pengantin). Nama dari tari Mapak yang digunakan tergantung dengan kebutuhan masyarakat sehingga oleh sebab itu tari ini menggunakan banyak nama lain.

Tari Mapak Adat Muara Kuang adalah tari tradisional dari Kelurahan Muara Kuang Kecamatan Muara Kuang, tari ini digunakan untuk upacara adat penyambutan tamu. Biasanya Tari Mapak Adat Muara Kuang ditarikan oleh penari wanita mulai dari remaja hingga lansia yang berjumlah ganjil mulai dari 3 , 5,7 dan seterusnya. Namun tari ini lebih sering ditampilkan dengan jumlah 5 orang penari, dimana penari yang paling depan membawa tepak yang berisikan daun sirih, pinang, kapur, gambir, dan tembakau yang akan diberikan kepada tamu kehormatan pada acara yang dilaksanakan. Prosesi pemberian sirih 
kepada tamu ini menjadi salah satu ciri keramahtamahan dan keterbukaan masyarakat Muara Kuang di Kabupaten Ogan llir dalam menyambut tamu.

Tari Mapak Adat Muara Kuang ini belum banyak diketahui oleh masyarakat daerah Kabupaten Ogan Ilir dengan alasan bahwa masyarakat tidak mengetahui gerakan dari tari ini, sehingga banyak anak-anak yang tidak mengetahui dan menarikannya. Bahkan tari ini sekarang hanya bisa dilihat pada acara pernikahan orang-orang tertentu saja, karena banyak orang yang lebih suka menarikan tarian seperti tari pagar pengantin dan tanggai pada acara pernikahan, hal ini disebabkan kurangnya minat masyarakat dalam melestarikan kesenian yang ada di Kecamatan Muara Kuang Kabupaten Ogan Ilir, sehingga masyarakat dan generasi muda tidak mengetahui dan memahami tentang fungsi tari tersebut, terutama generasi muda yang kurangnya pengetahuan tentang kesenian daerahnya sendiri.

Seni tari tentu memiliki fungsi bagi masyarakat yang berada di dekat kesenian tari tersebut. Menurut (Soedarsono, $1972:$ 22) tari dapat berfungsi sebagai : (1) Sarana upacara, (2) Sarana hiburan, (3) Sarana tontonan.

Berdasarkan gambaran di atas penulis tertarik untuk melakukan penelitian ini, karena peneliti ingin mengetahui dan mendapat informasi yang jelas terhadap tari tradisional khususnya tari Mapak adat Muara Kuang yang ada di Kecamatan Muara Kuang Kabupaten Ogan llir agar dapat dikembangkan dan dilestarikan oleh masyarakat. Atas dasar hal tersebut peneliti mencoba melakukan penelitian tentang "Fungsi Tari Mapak Adat Muara Kuang Sebagai Tari Sambut Pada Kecamatan Muara Kuang Kabupaten Ogan Ilir".

\section{B. METODE PENELITIAN}

Sebuah penelitian harus menggunakan metode yang dapat dipertanggungjawabkan kebenarannya. Dengan demikian, metode yang digunakan harus sesuai dengan objek, jenis dan tujuan penelitian agar apa yang menjadi tujuan sebuah penelitian dapat tercapai. Menurut (Heriyawati, 2016 : 71) metode penelitian merupakan cara ilmiah untuk mendapatkan data dengan tujuan dan kegunaan tertentu. 
Penelitian ini menggunakan metode penelitian kualitatif yang bersifat deskriptif yaitu menyajikan data dengan menggunakan kalimat-kalimat berupa teks. Metode penelitian kualitatif adalah proses penelitian dimulai dengan menyusun asumsi dasar dan aturan berfikir yang akan digunakan dalam penelitian. Asumsi dan aturan berpikir tersebut selanjutnya diterapkan secara sistematis dalam pengumpulan dan pengolahan data untuk memberikan penjelasan dan argumentasi. Dalam penelitian kualitatif, informasi yang dikumpulkan dan diolah harus tetap objektif dan tidak dipengaruhi oleh pendapat peneliti sendiri. (Heriyawati, $2016: 72$ ).

Berdasarkan pokok masalah yang dikaji, yang berjudul Fungsi Tari Mapak Adap Muara Kuang Sebagai Tari Sambut Pada Kecamatan Muara Kuang Kabupaten Ogan llir. Maka penelitian ini menggunakan metode penelitian kualitatif yang bersifat deskriptif. Selain menggunakan metode kualitatif penulis juga mendapatkan data dengan menggunakan observasi, wawancara dan dokumentasi.

\section{HASIL PENELITIAN DAN PEMBAHASAN}

Seni merupakan usaha manusia untuk menciptakan bentuk-bentuk yang menyenangkan. Bentuk-bentuk yang menyenangkan dalam arti bentuk yang dapat dibingkai perasaan keindahan dan perasaan keindahan itu dapat terpuaskan apabila dapat menangkap harmoni atau satu kesatuan dari bentuk yang disajikan (Read, H 1959:17 dalam Kherid 2020). Sedangkan menurut Ki Hajar Dewantara (Mulyani, 2016 : 12) seni adalah segala perbuatan manusia yang timbul dari perasaan hidupnya dan bersifat indah hingga dapat menggerakan jiwa perasaan manusia.

Tari merupakan salah satu jenis kesenian yang menggunakan tubuh sebagai alat utama dan gerak menjadi media dasar dalam mengungkapkan ekspresi jiwa manusia yang dituangksan melalui gerak yang indah. Seni tari menurut (Jazuli, $2008: 7$ ) tari adalah bentuk gerak yang indah, lahir dari tubuh yang bergerak, berirama dan berjiwa sesuai dengan maksud dan tujuan tari. Sedangkan menurut Soedarsono (dalam Hadi Dkk, 2018), " tari adalah sebagai ekspresi jiwa manusia yang diungkapkan dengan gerak ritmis dan indah". Seni tari 
secata garis besar adalah gerak tubuh secara berirama yang dilakukan di sebuah tempat dan waktu tertentu untuk mengungkapkan perasaan, pikiran dan maksud tertentu.

\section{Fungsi Tari}

$$
\begin{aligned}
& \text { (Rochayati \& Hera, } \\
& \text { Penciptaan karya tari } \\
& \text { harus diciptakan dan } \\
& \text { dirancang secara kreatif } \\
& \text { berlandaskan estetika } \\
& \text { sebagai unsur } \\
& \text { penciptaan. Secara } \\
& \text { prosedural, proses } \\
& \text { penciptaan karya tari } \\
& \text { dapat dilakukan atas } \\
& \text { dasar motivasi } \\
& \text { koreografer.Proses } \\
& \text { penciptaan tarian adalah } \\
& \text { proses kreasi. Proses ini } \\
& \text { akan terjadi dari } \\
& \text { beberapa langkah yaitu } \\
& \text { menetapkan tujuan } \\
& \text { penciptaan tari. Hal ini } \\
& \text { berkaitan dengan fungsi } \\
& \text { tarian yang akan } \\
& \text { dibuat.untuk keperluan } \\
& \text { apakah tarian itu } \\
& \text { diciptakan. Apakah } \\
& \text { untuk upacara, untuk } \\
& \text { tujuan estetika belaka, } \\
& \text { ataukah untuk tujuan } \\
& \text { lainnya. }
\end{aligned}
$$

Fungsi seni pertunjukan tari merupakan aktivitas kesenian dalam suatu konteks sosial, budaya, pariwisata dan ekonomi dalam suatu acara yang membutuhkan, didukung oleh masyarakat sebagai penonton sehingga kesenian tersebut benar berperan sebagai sebuah tontonan dan hiburan (Hera T. , 2018 : 389). Menurut (Soedarsono, $1972: 22$ ) fungsi seni tari dalam kehidupan manusia, setidaknya secara garis besar dikelompokan menjadi tiga macam, yaitu sebagai: (1) sarana upacara, (2) sarana hiburan, (3) sarana tontonan. Untuk lebih lengkapnya, dijelaskan dibawah ini :

\section{Tari Sebagai Sarana Upacara}

Upacara merupakan suatu tindakan atau serangkaian tindakan yang dilakukan menurut adat kebiasaan atau keagamaan yang menandai kesakralan atau kehidmatan suatu peristiwa. Serangkaian tindakan tersebut dilakukan berulang-ulang, dan berhubungan dengan kehidupan sehari-hari, alam, lingkungan, serta "penguasanya".

\section{Tari Sebagai Hiburan}

Seni tari sebagai hiburan digunakan dalam rangka memeriahkan suasana pesta hari perkawinan, khitanan, syukuran, peringatan hari-hari besar nasional, peresmian-peresmian gedung, dan lain sebagainya. Seni tari dalam acara-acara tersebut, sebagai ungkapan rasa senang dan bersyukur, yang diharapkan disisi lain juga menjadi ajang hiburan buat masyarakat pada 
umumnya. Masyarakat yang diundang atau hadir dalam acara tersebut, pada dasarnya juga mempunyai keinginan untuk menghibur diri atau rekreasi.

\section{Tari Sebagai Tontonan}

Tari tontonan atau disebut juga dengan tari pertunjukkan, dalam pelaksanaannya disajikan khusus untuk dinikmati. Tari yang berfungsi sebagai tontonan ini dapat diamati pada pertunjukan tari untuk kemasan pariwisata, untuk penyambutan tamutamu penting atau tamu pejabat, dan untuk festival seni. Pertunjukan tari yang dipergunakan pada acara-acara tersebut, penggarapannya sudah dikemas dan dipersiapkan menjadi sebuah tari bentuk yang telah melewati suatu proses penataan, baik gerak tarinya maupun musik iringannya sesuai dengan kaidahkaidah artistiknya.

Fungsi tari menurut Soedarsono berkaitan dengan fungsi tari Mapak Adat Muara Kuang yang sedang diteliti oleh peneliti yaitu tari Mapak Adat Muara Kuang mempunyai 3 fungsi : (1) ritual keagamaan seperti pada saat acara tardisi selamatan rumah. (2) sebagai hiburan pada pesta pernikahan dan (3) sebagai tontonan yaitu tari Mapak Adat
Muara Kuang ditarikan pada saat ada acara penyambutan tamu agung.

Tari Mapak Adat Muara Kuang awalnya dikenal dengan nama tari Papakan yang merupakan tari tradisional khas dari Kecamatan Muara Kuang terkhususnya Kelurahan Muara Kuang sebagai tempat kelahiran tari tersebut. Tari ini sudah ada sejak zaman penjajahan Belanda yang diciptakan oleh leluhur Kelurahan Muara Kuang \pm pada tahun 1930-an dengan menggunakan alat musik pengiring seperti gambus, gamelan dan gong. Tari Mapak Adat Muara Kuang dahulunya digunakan untuk penyambutan pimpinan Belanda yang pada saat itu menjajah Kelurahan Muara Kuang, akan tetapi setelah Indonesia merdeka tidak ada lagi masyarakat yang ingin menari dan menyambut kedatangan Belanda, sehingga Belanda marah dan membuang alat musik yang digunakan pada saat itu ke Sungai Ogan. Meskipun demikian tari ini tetap dilestarikan dan diajarkan secara turun menurun dari generasi kegenerasi. (Saribana Nanguning komunikasi pribadi, 14 Maret 2020).

Pada tahun 1970-an tari Mapak Adat Muara Kuang mulai dipopulerkan dan dikembangkan lagi, untuk tetap 
menjaga warisan budaya yang ada di Kelurahan Muara Kuang, di tahun 1970an ini mengalami perubahan alat musik pengiring yang digunakan pada tahun 1930-an seperti gambus, gamelan dan gong yang diubah menjadi sebuah gitar tunggal tanpa merubah nada dan tempo iringan musik sebelumnya, dengan alasan bahwa gitar tunggal dianggap lebih praktis karena tidak memerlukan banyak orang dalam memainkan alat musik pengiring tari Mapak Adat Muara Kuang. Alunan petikan gitar tunggal yang diikuti dengan Tembang Nasib dianggap membuat tari Mapak Adat Muara Kuang nampak lebih sendu dan menyentuh hati bagi penikmatnya terutama bagi masyarakat yang sudah lama tidak pulang ke kampung halaman. Dengan adanya perubahan alat musik iringan pada tari Mapak Adat Muara Kuang membuat tari ini seringkali mengikuti lomba ke tingkat kecamatan, kabupaten dan provinsi bahkan tari ini sering mendapatkan penghargaan. (Saribana Nanguning komunikasi pribadi, 14 Maret 2020).

Menurut Murtasia (komunikasi pribadi, 16 Maret 2020), tari Mapak Adat Muara Kuang hanya boleh ditarikan oleh penari wanita mulai dari remaja hingga lansia, dengan jumlah penari ganjil dari 3, 5, 7 dan seterusnya, tetapi tari ini lebih sering ditarikan oleh lima orang penari. Pada zaman dahulu sebelum pertunjukan tari Mapak Adat Muara Kuang, semua penari dibacakan ritual doa khusus yang dilakukan oleh leluhur Muara Kuang agar semua penari merasa lebih percaya diri dan lemah gemulai, akan tetapi dengan perkembangan zaman, ritual doa tersebut pada saat ini sudah tidak digunakan lagi. Pada tahun 1970-an tari Mapak Adat Muara Kuang sering digunakan untuk Memapak Pesirah dan Demang yang merupakan orang terhormat atau pimpinan suatu daerah. Pada saat kedatangan tamu agung para penari mulai menyambut tamu kehormatan dengan mengalungkan karangan bunga, kemudian saat tari berlangsung penari yang membawa Tepak Sirih meminta kepada tamu kehormatan untuk memakan daun sirih, kapur, pinang, gambir dan tembakau yang telah disediakan, tradisi ini merupakan bentuk keterbukaan dan keramahtamahan masyarakat Muara Kuang dalam penyambutan tamu yang datang ke daerahnya. Selain digunakan untuk penyambutan tamu agung tari Mapak Adat Muara Kuang juga 
digunakan untuk Memapak Pengantin, yang ditarikan untuk menghibur para undangan yang datang. Saat tari ini mulai dipertunjukan di acara pernikahan, tak jarang ada sanak saudara yang merasa sedih karena sudah lama tidak pulang ke kampung halaman. Adapun menurut $\mathrm{Hj}$. Nuraini (komunikasi pribadi, 20 Maret 2020) yang merupakan masyarakat Muara Kuang, beliau mengatakan bahwa tari Mapak Adat Muara Kuang dulu sering ditarikan pada acara selamatan rumah yang merupakan salah satu kebiasaan masyarakat dahulu sebelum menempati rumah yang telah dibangun. Upacara selamatan rumah dihadiri masyarakat sekitar untuk mendoakan supaya rumah tersebut tidak ada gangguan dari makhluk halus. Pada acara selamatan rumah tersebut tari Mapak Adat Muara Kuan ini ditampilakan pada saat pembukaan sebelum memulai acara. Namun pada saat ini tari Mapak Adat Muara Kuang tidak pernah lagi ditarikan pada acara selamatan rumah di Kelurahan Muara Kuang, karena masyarakat menganggap jika pada acara selamatan rumah menggunakan tari Mapak Adat Muara Kuang akan menambah biaya, oleh sebab itu masyarakat Muara Kuang sudah meninggalkan tradisi tersebut. Disamping itu juga kepercayaan masyarakat sekarang sudah berbeda dengan masyarakat dulu, yang mana masyarakat sekarang lebih menyukai hal yang dianggap lebih mudah dan mempersingkat waktu

Sependapat dengan Hj. Nuraini, Firdaus (Komunikasi Pribadi, 18 Maret 2020) tari Mapak Adat Muara Kuang merupakan warisan budaya dan sudah menjadi identitas masyarakat Kecamatan Muara Kuang, keberadaan tari Mapak Adat Muara Kuang merupakan wujud bahwa masyarakat masih melestarikan tari ini hingga sekarang. Tari Mapak Adat Muara Kuang sendiri memiliki fungsi sebagai sarana upacara dalam tradisi selamatan rumah, fungsi sebagai tontonan seperti pada acara penyambutan tamu agung yang datang ke daerah Muara Kuang, dan fungsi lainnya yaitu sebagai hiburan seperti acara pernikahan masyarakat Muara Kuang.

Pada tahun 1970-an busana yang dikenakan penari Mapak Adat Muara Kuang sangatlah sederhana yaitu mengunakan Baju Kurung berwarna kuning atau hitam dan Kain tetoron berwarna merah dengan diberi corak 
lingkaran atau seperti koin emas serta aksesoris yang digunakan seperti Sanggul Solo, Bunga Cempako, Bunga Karangan dari Daun Pandan, Melati dan Kamboja sebagai pengganti Bunga Rampai, Anting, Selendang yang terbuat dari kain songket ataupun semacamnya, Tanggai serta Gandik, Paksangko dan Kalung untuk penari paling depan (Murida komunikasi pribadi 17 Maret 2020). Adapun menurut $(\mathrm{Hj}$. Nuraini komunikasi pribadi, 20 Maret 2020) pakaian tari Mapak Adat Muara Kuang pada tahun 1980-an juga sering ditampilkan dengan pakaian dodotan seperti Sewet Songket dan Kemben Songket dengan aksesoris yang digunakan seperti Gandik, Sanggul Malang, Bunga Cempako, Bunga Rampai, Teratai, Kalung, Pending, Gelang Burung (Kecak Bahu) dan Tanggai. Sedangkan menurut Rukiah (komunikasi pribadi, 19 Maret 2020) tata busana tari Mapak Adat Muara Kuang sekarang sebernarnya tidak jauh berbeda, hanya saja sudah menyesuikan dengan perkembangan zaman yaitu mengunkan Baju Kurung dan Kain berwarna merah yang menyimbolkan keberanian, pada Baju Kurung dan Kain ini dapat diberi corak bermotif songket yang sama dan senada sehingga akan membuat busana tari Mapak Adat Muara Kuang terlihat lebih indah dan terkesan lebih mewah. Adapun aksesoris yang digunakan pada tari Mapak Adat Muara Kuang seperti Paksangko, Gandik, Cempako, Sanggul, Bunga Rampai, Anting, Teratai, Kalung, Selempang, Pending dan Tanggai.

Tari upacara selamatan rumah menurut $\mathrm{Hj}$. Nuraini (komunikasi pribadi, 20 Maret 2020) yang merupakan masyarakat Muara Kuang, beliau mengatakan bahwa tari Mapak Adat Muara Kuang dulu sering ditarikan pada acara selamatan rumah yang merupakan salah satu kebiasaan masyarakat dahulu sebelum menempati rumah yang telah dibangun. Upacara selamatan rumah dihadiri masyarakat sekitar untuk mendoakan supaya rumah tersebut tidak ada gangguan dari makhluk halus. Pada acara selamatan rumah tersebut tari Mapak Adat Muara Kuang ini ditampilakan pada saat pembukaan sebelum memulai acara. 


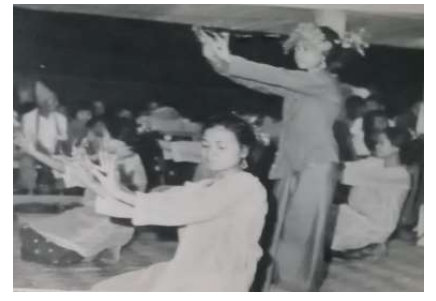

Tari Mapak Adat Muara Kuang dalam upacara selamatan rumah Sumber : Ibu

Saribana Nanguning 1972

Namun pada saat ini tari Mapak

Adat Muara Kuang tidak lagi dipertunjukan sebagai fungsi sarana upacara ritual dalam tradisi selamatan rumah. Perubahkan ini terjadi akibat adanya pengaruh dari perkembangan zaman yang menyebabkan masyarakat meningalkan kebisaan-kebiasaan lama dan lebih menyukai hal yang praktis, akibat dari hal tersebut masyarakat mulai terpengaruh untuk meniru budaya baru dan meningalkan budaya dan tradisi lama.

Tari hiburan Mapak Adat Muara Kuang digunakan pada acara pernikahan, khitanan dan juga pesta rakya Muara Kuang, artinya tari ini berfungsi sebagai hiburan. Setiap upacara adat pernikahan masyarakat Muara Kuang tuan rumah diwajibkan untuk menampilkan tari Mapak Adat Muara Kuang yang ditarikan untuk menghibur para tamu undangan yang hadir dalam acara pesta pernikahan tersebut. Pada saat tari Mapak Adat Muara Kuang dipertunjukan dalam acara pernikan, masyarakat sangat antusias dalam menyaksikan tari tersebut.

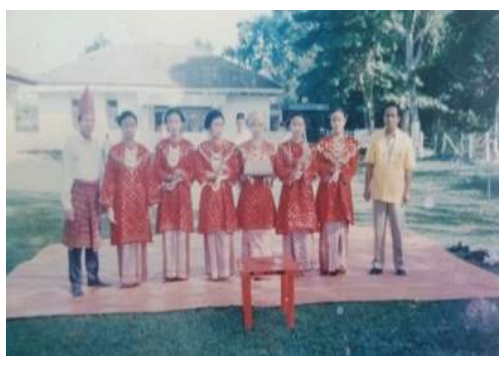

Tari Mapak Adat Muara Kuang dalam acara Penyambutan Tamu Sumber : Ibu Seni Apria 1995

Tari tontonan pada saat kedatangan tamu agung para penari mulai menyambut tamu kehormatan dengan mengalungkan karangan bunga, kemudian saat tari berlangsung penari yang membawa Tepak Sirih meminta kepada tamu kehormatan untuk memakan daun sirih, kapur, pinang, gambir dan tembakau yang telah disediakan, tradisi ini merupakan bentuk keterbukaan dan keramahtamahan masyarakat Muara Kuang dalam penyambutan tamu yang datang ke daerahnya. 


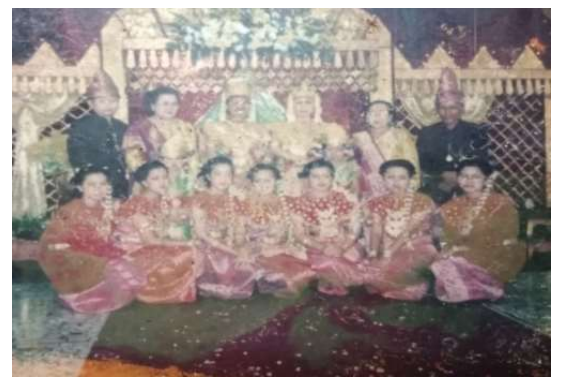

Tari Mapak Adat Muara Kuang dalam acara Pernikahan Sumber : Ibu Seni Apria 1995

Pada saat ini tari Mapak Adat

Muara Kuang di daerah Muara Kuang hanya pada acara hiburan pernikahan khususnya di daerah Muara Kuang dan juga digunakan sebagai tari penyambutan tamu agung yang datang kedaerah Muara Kuang.

\section{SIMPULAN}

Hasil dari penelitian yang diperoleh dari observasi, wawancara, dan dokumentasi mengenai fungsi tari Mapak Adat Muara Kuang sebagai tari sambut pada Kecamatan Muara Kuang Kabupaten Ogan llir memiliki tiga fungsi, bahwa tari Mapak Adat Muara Kuang berfungsi sebagai sarana upacara ritual bagi masyarakat yang menjadi pelengkap dalam prosesi acara selamatan rumah, fungsi sebagai hiburan bagi masyarakat seperti pada acara pernikahan, khitanan dan pesta rakyat. Serta berfungsi sebagai tontonan bagi masyarakat yang dikhususkan pada acara penyambutan tamu agung.

Pada saat ini tari Mapak Adat Muara Kuang tidak lagi dipertunjukan sebagai fungsi sarana upacara ritual dalam tradisi selamatan rumah. Perubahkan ini terjadi akibat adanya pengaruh dari perkembangan zaman yang menyebabkan masyarakat meningalkan kebisaan-kebiasaan lama dan lebih menyukai hal yang praktis, akibat dari hal tersebut masyarakat mulai terpengaruh untuk meniru budaya baru dan meningalkan budaya dan tradisi lama.

\section{DAFTAR PUSTAKA}

Bahari, N. (2014). Kritik Seni. Yogyakarta : Pustaka Pelajar.

Hadi, Dkk. (2018). Kegiatan Ekstra Kurikuler Tari Tradisiona Meusree-Saree Di Sdit AlFityan Lampeuneurut Aceh Besar. Banda Aceh: Universitas Syiah Kuala. (Vol.III, No.1).

Hera, T. (2018). RANGSANG AUDIO SEBAGAI MOTIVASI PADA PENCIPTAAN KARYA TARI TUNGGU TUBANG DALAM PEMBELAJARAN KOREOGRAFI DI UNIVERSITAS PGRI PALEMBANG. JURNAL SITAKARA, 3(1), 58-68. 
Hera, T. (2018, July). ASPEK-ASPEK PENCIPTAAN TARI DALAM PENDIDIKAN. In Prosiding Seminar Nasional Program Pascasarjana Universitas PGRI Palembang (Vol. 5, No. 05).

Hera, T. (2019). Fungsi Tari Persembahan Tepak Sirih Dalam Memeriahkan Acara Hbd Indonesia Di Bkb Palembang. Jurnal Sitakara, 3(2), 60-68.

Heriyawati, Y. (2016). Seni Pertunjukan Dan Ritual . Yogyakarta: Penerbit Ombak .

Jazuli, M. (2008). Paradigma Kontekstual Pendidikan dan Seni. Semarang: Unesa University Press.

Kherid, Zaitun Y.A. (2020). Model Pembelajaran Kognitif dan Gender Tahap Hasil Karya Lukis. Jurnal Unj (Vol.03, No.01).

Koentjaraningrat. (2015). Pengantar ilmu Antropologi. Jakarta: Rineka Cipta.

Mulyani, N. (2016). Pendidikan Seni Tari Anak Usia Dini. Yogyakarta: Gava Media.

Rochayati, Rully, and Treny Hera. "ESTETIKA TARI MELAJU DENGAN MUTU." JURNAL SITAKARA 4.2 (2019): 21-29.

Soedarsono. (1972). Djawa dan Bali. Yogyakarta: Gadjah Mada University Press. 